\title{
Analisis Korelasi Self Efficacy dan Flow Akademik dengan Prestasi Belajar PAI di Smk YPM (Yayasan Pendidikan Maarif) 5 Sukodono Sidoarjo
}

\author{
Erma Ro'idhotul Jannah, ${ }^{1}$ Badrus ${ }^{2}$ \\ 1,2Institut Agama Islam Tribakti Kediri \\ 1ermanike@gmail.com,2badrus.kdr@gmail.com
}

\begin{abstract}
Abstrak
nelitian ini bertujuan untuk mengetahui besarnya hubungan (1) Self Efficacy, (2) Flow Akademik, (3) Prestasi Belajar PAI di Smk YPM (Yayasan Pendidikan Maarif) 5 Sukodono Sidoarjo. Pendekatan penelitian ini adalah penelitian kuantitatif korelasional. Teknik pengambilan sampelnya menggunakan cluster random reponden. Hasil Penelitian menunjukkan: 1) Ada hubungan positif yang signifikan antara self efficacy dengan prestasi belajar PAI kelas X di SMK YPM 5 Sukodono Sidoarjo. Hal ini ditunjukkan dengan koefisien regresi 0,046 dan signifikansi sebesar 0,000 (Sig > 0,05); 2) Ada hubungan positif yang signifikan antara flow akademik dengan prestasi belajar PAI kelas $X$ di SMK YPM 5 Sukodono Sidoarjo. Hal ini ditunjukkan dengan koefisien regresi 0,028 dan signifikansi sebesar 0,000 (Sig > 0,05); 3) Ada hubungan positif yang signifikan antara self efficacy dan flow akademik dengan prestasi belajar PAI kelas X di SMK YPM 5 Sukodono Sidoarjo. Hal ini ditunjukkan dengan koefisien regresi 0,52 dan 0.49 serta signifikansi sebesar 0,000 (Sig > $0,05)$.
\end{abstract}

Kata Kunci: Self Efficacy, Flow Akademik, Prestasi Belajar PAI

\section{Pendahuluan}

Pendidikan agama Islam

merupakan mata pelajaran yang wajib dipelajari di setiap jenjang pendidikan di Indonesia mulai dari SD, SMP, SMA bahkan sampai jenjang perguruan tinggi.

Masalah umum yang sering dihadapi guru dalam pembelajaran PAI adalah rendahnya minat siswa dalam mata pelajaran Pendidikan Agama Islam dibuktikan bahwa pengajaran
Pendidikan Agama Islam oleh guru-guru agama sangat tidak menarik bagi murid. sehingga monoton dan membosankan. Hal tersebut menunjukkan bahwa pengajaran Pendidikan Agama Islam 
Analisis Korelasi Self Efficacy dan Flow Akademik dengan Prestasi Belajar PAI di Smk YPM (Yayasan Pendidikan Maarif) 5 Sukodono Sidoarjo

Oleh: Erma Ro'idhotul Jannah, Badrus

membosankan. Ini tidak saja terjadi di Indonesia, tetapi juga di luar negeri. ${ }^{1}$

Untuk meningkatkan prestasi belajar PAI, pada dasarnya setiap siswa memiliki kemampuan untuk mempelajari mata pelajaran PAI, Persepsi tentang kemampuan diri ini disebut dengan self efficacy. Menurut Bandura (dalam Hadi Warsito, 2004) self Efficacy merupakan keyakinan individu bahwa dirinya mampu melakukan sesuatu dalam situasi tertentu dengan berhasil. ${ }^{2}$ Selain self efficacy, adanya fokus belajar siswa juga dapat mempengaruhi prestasi belajar PAI yang disebut dengan flow akademik. Dengan demikian, peneliti mengangkat sebuah penelitian dengan judul Hubungan antara Self Efficacy dan Flow akademik dengan Prestasi Belajar PAI di SMK YPM 5 Sukodono Sidoarjo.

Berdasarkan pembatasan masalah di atas, maka masalah dalam penelitian ini dirumuskan sebagai berikut:

1. Apakah terdapat hubungan positif antara self efficacy dengan prestasi belajar PAI di SMK YPM 5 Sukodono Sidoarjo?

1 Saifudin, PPIM: Pengajaran Pendidikan Agama Islam di SMP-SMA Tak Menarik, http://ppim.or.id/en/menu/berita/detail.php?r
2. Apakah terdapat hubungan positif antara flow akademik dengan prestasi belajar PAI di SMK YPM 5 Sukodono Sidoarjo?

3. Apakah terdapat hubungan positif antara selfefficacy dan flow akademik dengan prestasi belajar PAI di SMK YPM 5 Sukodono Sidoarjo?

\section{Kajian Teori}

\section{Self Efficacy}

Menurut Bandura (1997) self-efficacy adalah persepsi diri sendiri mengenai seberapa bagus diri dapat berfungsi dalam situasi tertentu. Self-efficacy berhubungan dengan keyakinan diri memiliki kemampuan melakukan tindakan yang diharapkan. Self-efficacy adalah penilaian diri, apakah dapat melakukan tindakan yang baik atau buruk, tepat atau salah, bisa atau tidak bisa mengerjakan sesuai dengan yang dipersyaratkan. Self-efficacy berbeda dengan aspirasi (cita-cita), karena citacita menggambarkan sesuatu yang ideal yang seharusnya (dapat dicapai), sedang self-efficacy menggambarkan penilaian

islam-di-smp-sma-tak-menarik-, diunduh pada pada hari selasa, 16 Juli 2019 pukul 10.55

${ }^{2}$ Hadi Warsito, 2004, Hubungan antara Self Efficacy dengan Penyesuaian akademik dan Prestasi Akademik. Jurnal Psikologi, Vol. 14, No. 2 
Analisis Korelasi Self Efficacy dan Flow Akademik dengan Prestasi Belajar PAI di Smk YPM (Yayasan Pendidikan Maarif) 5 Sukodono Sidoarjo

Oleh: Erma Ro'idhotul Jannah, Badrus

kemampuan diri A. Bandura (1997), Self Efficacy: the Exercise of Control. New York:Freeman. ${ }^{3}$

Jeanne E (2008) menyatakan bahwa self efficacy adalah keyakinan bahwa seseorang mampu menjalankan perilaku tertentu atau mencapai tujuan tertentu. ${ }^{4}$ Sedangkan menurut Robert A. Baron \& Donn Byrne self efficacy adalah keyakinan seseorang akan kemampuan atau kompetensinya atas kinerja tugas yang diberikan, mencapai tujuan atau mengatasi sebuah hambatan. ${ }^{5}$

\section{Flow Akademik}

Flow akademik didefinisikan sebagai kondisi ketika individu mampu fokus (absorption), merasa nyaman (enjoyment), dan termotivasi secara internal ketika belajar, mengerjakan tugas, ataupun kegiatan akademik lainnya. ${ }^{6}$ Sedangkan Elliot dan Dweck mendefinisikan flow akademik sebagai sebuah keterlibatan siswa dalam suatu kegiatan akademik sehingga melupakan

${ }^{3}$ Alwisol (2007), Psikologi kepribadian. UMM Press: Malang, hlm, 287.

4 Jeanne Ellis Ormrod (2008), Psikologi Pendidikan, Jakarta : ERLANGGA, hlm. 20

5 Robert A. Baron \& Donn Byrne (2003), Psikologi Sosial, Jakarta : ERLANGGA, hlm. 183

${ }^{6}$ Yuwanto, L., Siandhika, L., Budiman, A.F., \& Prasetyo, T.I (2011), Stres akademik dan flow akademik. Presented at Psychology Village 2 waktu, kelelahan dan hal-hal lainnya yang ada dalam pikiran mereka hanya kegiatan tersebut. ${ }^{7}$

Csikszentmihalyi (1996) mengawali penelitian tentang flow dengan mewawancarai beberapa orang tentang alasan mereka berkomitmen tinggi ketika melakukan sesuatu tanpa ada ganjaran eksternal yang jelas. Flow memberikan kontribusi pada performa yang optimal dan belajar. Ketika individu mengalami flow dalam belajar, ia akan memusatkan perhatiannya pada apa yang dipelajarinya. Karena menikmati kegiatan belajar, siswa tersebut akan lebih sulit terserang stress dan sebagai akibatnya dia akan merasa bahagia. Kebahagiaan yang dirasakannya saat belajar dapat membuat prestasinya meningkat. ${ }^{8}$

\section{Prestasi Belajar PAI}

Prestasi belajar PAI merupakan hal yang tidak dapat dipisahkan dari

Harmotion: It"s our nation, it"s our concern. Universitas Pelita Harapan Jakarta, in Jakarta, April 4

7 Elliot, A. J., Dweck (2005), Handbook of Competence and Motivation. New York, The Guilford Press

${ }^{8}$ Lucky P (2012), Pengalaman Flow dalam Belajar, JURNAL ILMU PERILKAU, Vol. 1, No. 1, 58-71 
Analisis Korelasi Self Efficacy dan Flow Akademik dengan Prestasi Belajar PAI di Smk YPM (Yayasan Pendidikan Maarif) 5 Sukodono Sidoarjo

Oleh: Erma Ro'ídhotul Jannah, Badrus

kegiatan belajar PAI, karena kegiatan belajar PAI merupakan proses, sedangkan prestasi merupakan hasil dari proses belajar. Winkel (dalam Cholil \& Kurniawan) menyatakan bahwa prestasi belajar adalah suatu bukti keberhasilan belajar atau kemampuan seorang siswa dalam melakukan kegiatan belajarnya sesuai dengan bobot yang dicapainya. ${ }^{9}$ Hal senada diungkapkan Suryabrata bahwa prestasi belajar atau prestasi akademik adalah seluruh hasil yang telah dicapai (achievement) melalui proses belajar akademik (academic achievement). ${ }^{10}$

Dari definisi tersebut dapat disimpulkan bahwa prestasi belajar PAI siswa adalah hasil belajar atau nilai yang dicapai oleh siswa setelah melakukan kegiatan belajar PAI dalam kurun waktu tertentu yang diukur dengan menggunakan tes.

Ralasi Self Efficacy dan Flow akademik dengan Prestasi Belajar PAI

Untuk menjelaskan keterkaitan antara self efficacy, flow akademik dengan prestasi belajar PAI digunakan

9 Cholil \& Kurniawan (2011), Psikologi Pendidikan Telaah Teoritik dan Praktik, Surabaya: IAIN Sunan Ampel Press, hlm. 23-24

10 Suryabrata S (2002), Psikologi pendidikan, Yogyakarta: PT. Raja grafindo Persada, hlm. 232
Conservation of Resource Theory (COR). menurut Conservation of Resource Theory (COR), individu akan berusaha untuk memperoleh dan mempertahankan sumber daya (resource) yang dimilikinya. Sumber daya tersebut meliputi sumber daya personal atau sumber daya pribadi dan sumber daya lingkungan (sumberdaya eksternal). Ancaman akan terjadi jika sumber daya tersebut hilang, akibatnya akan muncul keadaan negatif, contohnya akan mengalami stress. Akan tetapi jika sumber daya itu ada maka akan mencapai prestasi. Menurut Hobfoll (1989), apabila perilaku untuk melindungi atau menggantikan sumber daya ini tidak dimunculkan, maka sumber daya tersebut dapat sedemikian kering sehingga akan mengakibatkan terjadinya burnout. ${ }^{11}$

\section{Metode}

Penelitian ini menggunakan pendekatan kuantitatif. Penelitian dengan pendekatan kuantitatif menekankan analisisnya pada data numerikal (angka) yang diolah dengan

${ }^{11}$ Hobfoll, 1989, Conservation of Resources: A New Attempt at Conceptualizing Stress. American Psychologist, 44: 513-524 
metode statistika. ${ }^{12}$ Jenis penelitian kuantitatif yang digunakan adalah penelitian asosiatif. Jenis penelitian asosiatif yaitu penelitian yang bersifat menanyakan hubungan antara dua variabel atau lebih. Hubungan tersebut adalah hubungan kausal (sebab-akibat). Jadi, ada variabel independen (yang mempengaruhi) dan dependen (dipengaruhi).

Adapun tempat penelitian ini dilaksanakan di SMK YPM 5 Sukodono Sidoarjo dengan pertimbangan bahwa SMK YPM 5 Sukodono Sidoarjo sebagaimana sekolah sederajat lainnya adalah salah satu sekolah umum di kota Sidoarjo yang mengutakan pendidikan Agama Islam. Pengambilan data penelitian dilaksanakan pada hari selasa tanggal 19 Maret 2019.

\section{Hasil dan Pembahasan}

Dalam melakukan penelitian ini penulis menggunakan instrumen berupa kuesioner yang terdiri dari variabel self efficacy dan variabel flow akademik yang masing-masing berjumlah 20 item pertanyaan.
Tabel 4.5 Hasil Uji Estimasi Validitas

\begin{tabular}{|c|l|c|}
\hline Skala & $\begin{array}{c}\text { Koefisien } \\
\text { Validitas }\end{array}$ & $\begin{array}{c}\text { Jumlah } \\
\text { Aitem }\end{array}$ \\
\hline $\begin{array}{c}\text { Flow } \\
\text { Akademik }\end{array}$ & 0,802 & 20 \\
\hline Self Efficacy & 0,839 & 20 \\
\hline
\end{tabular}

Berdasarkan dari uji validitas menunjukkan bahwa nilai $r$ hitung lebih besar dibanding nilai $\mathrm{r}$ tabel 0.205. Maka seluruh butir soal dinyatakan valid.

\begin{tabular}{|c|l|c|}
\hline Skala & $\begin{array}{l}\text { Koefisien } \\
\text { eliabilitas }\end{array}$ & Jumlah Aitem \\
\hline $\begin{array}{c}\text { Flow } \\
\text { Akademik }\end{array}$ & 0,902 & 20 \\
\hline Self Efficacy & 0,935 & 20 \\
\hline
\end{tabular}

Hasil uji reliabilitas variabel flow akademik, diperoleh nilai reliabilitas sebesar 0,902 maka reliabilitas alat ukur adalah baik, sedangkan untuk variabel self efficacy diperoleh nilai reliabilitasnya adalah 0,935 maka reliabilitasnya adalah baik. Kedua variabel memiliki reliabilitas yang baik, artinya aitem-aitemnya sangat reliabel sebagai alat pengumpul data dalam penelitian ini. Dikatakan sangat reliabel karena nilai koefisiensi lebih dari 0,70 dan mendekati 1,00. 


\section{Uji Normalitas}

\begin{tabular}{|l|c|c|c|}
\hline \multirow{2}{*}{ Variabel } & \multicolumn{2}{|c|}{ Shapiro-Wilk } & \multirow{2}{*}{ Keterangan } \\
\cline { 2 - 3 } & Df & Signifikansi & \\
\hline $\begin{array}{l}\text { Flow } \\
\text { Akademik }\end{array}$ & 22 & 0,806 & Normal \\
\hline Self_Efficacy & 22 & 0,268 & Normal \\
\hline
\end{tabular}

Dari hasil tabel diatas diperoleh nilai signifikansi untuk skala flow sebesar 0,806 > 0,05 sedangkan nilai signifikansi untuk skala self efficacy sebesar 0,268 > 0,05. Karena nilai signifikansi kedua skala tersebut lebih dari 0,05 maka dapat dikatakan bahwa data tersebut berdistribusi normal dan model ini memenuhi asumsi uji normalitas.

\section{Uji Linieritas}

\begin{tabular}{|l|c|c|}
\hline \multicolumn{1}{|c|}{ Variabel } & Signifikansi & Keterangan \\
\hline $\begin{array}{l}\text { Self Efficacy - } \\
\text { Prestasi Belajar }\end{array}$ & 0.002 & Linier \\
Flow & & \\
Akademik - & 0.003 & Linier \\
Prestasi Belajar & & \\
\hline
\end{tabular}

Hasil uji linearitas antara variabel flow akademik dengan self efficacy menunjukkan taraf signifikansi sebesar 0,003 $<0,05$ yang artinya bahwa variabel self efficacy dan Prestasi Belajar mempunyai hubungan yang linier. Sedangkan hubungan antara Flow akademik dan Prestasi Belajar tidak linier.
Uji Hipotesis Self Efficacy dengan

\section{Prestasi Belajar}

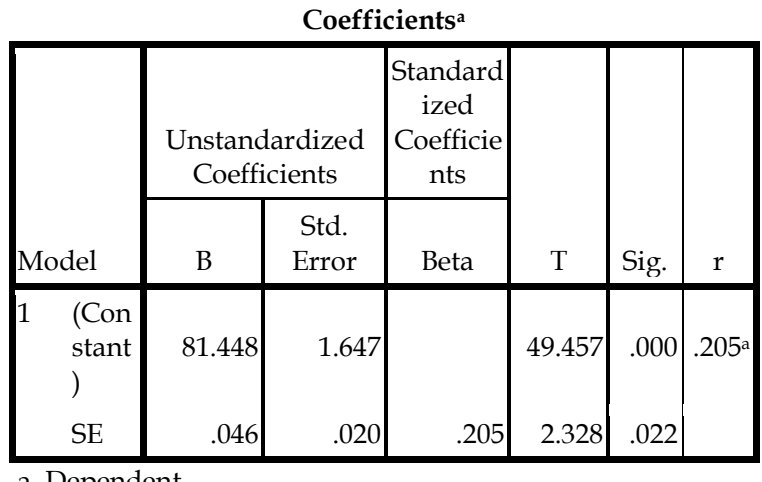

a. Dependent

Variable: Prestas Belajar

Hasil uji hubungan antara self efficacy dengan prestasi belajar PAI didapatkan Ho ditolak, berarti ada hubungan positif antara self efficacy dengan prestasi belajar PAI dengan nilai $\mathrm{r}=0,205$ dan nilai signifikansi .000 yang artinya kurang dari 0.05. Nilai koefisien korelasi positif $(+)$ atau searah, artinya jika self efficacy semakin tinggi maka prestasi belajar PAI semakin tinggi pula. Sumbangan efektif self efficacy pada presatsi belajar PAI yaitu 0.205 atau $20.5 \%$. Nilai tersebut berarti $20.5 \%$ perubahan pada prestasi belajar PAI dapat diterangkan oleh self efficacy. 
Uji Hipotesis Flow Akademik dengan

\section{Prestasi Belajar}

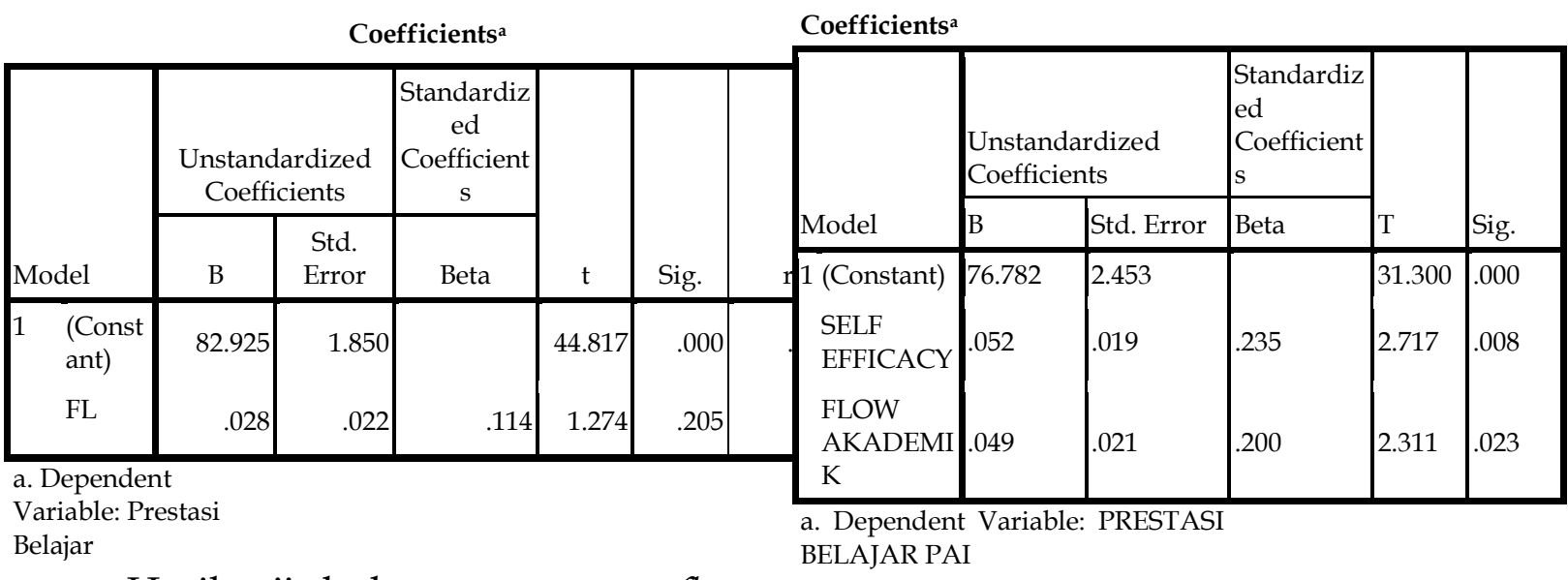

Uji Hipotesis Self Efficacy dan Flow

\section{Akademik dengan Prestasi Belajar}

Coefficients $^{\mathrm{a}}$
Hasil uji hubungan antara self akademik dengan prestasi belajar PAI didapatkan Ho ditolak, berarti ada hubungan positif antara flow akademik dengan prestasi belajar PAI dengan nilai $r=0,114$ dan nilai signifikansi .000 yang artinya kurang dari 0.05. Nilai koefisien korelasi positif $(+)$ atau searah, artinya jika flow akademik semakin tinggi maka prestasi belajar PAI semakin tinggi pula. Sumbangan efektif flow akademik pada presatsi belajar matematika yaitu 0.114 atau $11.4 \%$. Nilai tersebut berarti $11.4 \%$ perubahan pada prestasi belajar PAI dapat diterangkan oleh flow akademik. efficacy dan flow akademik dengan prestasi belajar PAI didapatkan Ho ditolak, berarti ada hubungan positif antara self efficacy dan flow akademik dengan prestasi belajar PAI dengan nilai $\mathrm{r}=0,302$ dan nilai signifikansi .000 yang artinya kurang dari 0.05. Nilai koefisien korelasi positif $(+)$ atau searah, artinya jika self efficacy dan flow akademik semakin tinggi maka prestasi belajar PAI semakin tinggi pula. Sumbangan efektif self efficacy dan flow akademik pada presatsi belajar matematika yaitu 0.302 atau $30.2 \%$. Nilai tersebut berarti $30.2 \%$ perubahan pada prestasi belajar PAI dapat diterangkan oleh self efficacy dan flow akademik. 
Analisis Korelasi Self Efficacy dan Flow Akademik dengan Prestasi Belajar PAI di Smk YPM (Yayasan Pendidikan Maarif) 5 Sukodono Sidoarjo

Oleh: Erma Ro'idhotul Jannah, Badrus

\section{Analisis Data}

\section{Self Efficacy dengan Prestasi Belajar}

Hubungan positif antara self efficacy dengan prestasi belajar PAI terjadi karena self efficacy menurut Schunk dan Meece, 2005 (dalam Harida, 2012) akan mempengaruhi pilihan tugas, tenaga, ketekunan, dan prestasi siswa. ${ }^{13}$ Self efficacy juga akan mempengaruhi tindakan yang akan dilakukan siswa, besarnya usaha yang dilakukan serta ketahanan siswa dalam menghadapi rintangan, kegagalan, stress dan depresi yang dialami Bandura, 1997 dalam (Alwisol (2007). ${ }^{14}$ Bagi siswa yang memiliki self efficacy, kegagalan tidak akan membuatnya putus asa, tetapi siswa tersebut akan memaknai kegagalan sebagai cambuk untuk dapat lebih giat dalam berusaha dan menjadikan kegagalan itu sebagai sebuah langkah awal untuk mencapai keberhasilan sehingga siswa akan terus berusaha untuk memperbaiki usaha-usaha yang dilakukan sebelumnya untuk mencapai keberhasilan.

\section{Flow Akademik dengan Prestasi} Belajar

Hubungan positif antara flow akademik dengan prestasi belajar PAI terjadi karena dalam keadaan flow akademik siswa akan lebih fokus dalam belajar dengan menunjukkan kreatifitas sehingga materi menjadi lebih mudah terserap dan prestasi belajar menjadi lebih baik Csikszentmihalyi (1996) dalam (Lucky P, 2012). ${ }^{15}$

\section{Self Efficacy dan Flow Akademik} dengan Prestasi Belajar

Adanya hubungan antara self efficacy dan flow akademik dengan prestasi belajar PAI dapat dijelaskan dengan menggunakan pendapat Schunk dan Meece (2005) dan Csikszentmihalyi (1996). Siswa yang memiliki self efficacy menurut Bandura (1997) memiliki keyakinan dan kemampuannya untuk menyelesaikan tugas yang diberikan dan mengatasi hambatan yang muncul sehingga akan mendatanagkan hasil yang diharapkan. Dengan perasaan yakin akan kemampuannya, siswa akan lebih tekun,

14 Alwisol (2007), Psikologi kepribadian. UMM Press: Malang, hlm, 287

15 Lucky P (2012), Pengalaman Flow dalam Belajar, JURNAL ILMU PERILKAU, Vol. 1, No. 1, 58-71 
mengeluarkan usaha lebih banyak dalam menyelesaikan tugas PAI serta tidak mudah menyerah dalam menghadapi tantangan. Menurut Csikszentmihalyi (1996), siswa yang mengalami flow akademik akan sepenuhnya tenggelam dalam melakukan kegiatan akademiknya, berkonsentrasi penuh dan mengalami kenikmatan dalam menyelesaikan kegiatan akademiknya. Untuk berada dalam keadaan flow akademik, siswa perlu memiliki keseimbangan antara tantangan tugas akademik dan keyakinan akan kemampuan siswa untuk menyelesaikan tugas akademik dengan baik. Dengan demikian siswa yang berada dalam keadaan flow akademik akan cenderung memiliki komitmen, ketekunan dan seff efficacy yang akan meningkatkan prestasi belajar PAI siswa.

\section{Kesimpulan}

1. Ada hubungan positif yang signifikan antara self efficacy dengan prestasi belajar PAI kelas $X$ di SMK YPM 5 Sukodono Sidoarjo. Hal ini ditunjukkan dengan koefisien regresi 0,046 dan signifikansi sebesar 0,000 $(\operatorname{Sig}>0,05)$.
2. Ada hubungan positif yang signifikan antara flow akademik dengan prestasi belajar PAI kelas $\mathrm{X}$ di SMK YPM 5 Sukodono Sidoarjo. Hal ini ditunjukkan dengan koefisien regresi 0,028 dan signifikansi sebesar 0,000 $(\operatorname{Sig}>0,05)$.

3. Ada hubungan positif yang signifikan antara self efficacy dan flow akademik dengan prestasi belajar PAI kelas $\mathrm{X}$ di SMK YPM 5 Sukodono Sidoarjo. Hal ini ditunjukkan dengan koefisien regresi 0,52 dan 0.49 serta signifikansi sebesar 0,000 (Sig > 0,05).

\section{Daftar Pustaka}

Alwisol. Psikologi kepribadian. UMM Press: Malang, 2007.

AlwisolPsikologi kepribadian. UMM Press: Malang, 2007.

Cholil \& Kurniawan. Psikologi Pendidikan Telaah Teoritik dan Praktik, Surabaya: IAIN Sunan Ampel Press, 2011.

Elliot, A. J., Dweck Handbook of Competence and Motivation. New York, The Guilford Press, 2005.

Harida dan Marhaeny W. Self Efficacy dan Prestasi Belajar Siswa dalam Pembelajaran Kimia, Jurnal pendidikan Matematika dan IPA, Vol. 3, No. 1 (2012) 
Analisis Korelasi Self Efficacy dan Flow Akademik dengan Prestasi Belajar PAI di Smk YPM (Yayasan Pendidikan Maarif) 5 Sukodono Sidoarjo

Oleh: Erma Ro'idhotul Jannah, Badrus

Hobfoll, Conservation of Resources: A New Attempt at Conceptualizing Stress. American Psychologist, 44: $1989,513-524$

Lucky P Pengalaman Flow dalam Belajar, JURNAL ILMU PERILKAU, Vol. 1, No. 1, (2012), 58-71

Lucky P. Pengalaman Flow dalam Belajar, JURNAL ILMU PERILKAU, Vol. 1, No. 1, (2012), 58-71

Ormrod, Jeanne Ellis. Psikologi Pendidikan, Jakarta : ERLANGGA.

Robert A. Baron \& Donn Byrne Psikologi Sosial, Jakarta : ERLANGGA, 2003.

Saifudin, PPIM: Pengajaran Pendidikan Agama Islam di SMP-SMA Tak Menarik,

http://ppim.or.id/en/menu/berit a/detail.php? $r=20121214083330$ pengajaran-pendidikan-agama islam-di-smp-sma-tak-menarik- , diunduh pada pada hari selasa, 16 Juli 2019 pukul 10.55

Suranto, Metodologi Penelitian dalam Pendidikan Dengan Progran SPSS, Semarang: CV. Ghiyyas Putra, 2009.

Suryabrata S. Psikologi pendidikan, Yogyakarta: PT. Raja grafindo Persada, 2002.

Warsito, Hadi. Hubungan antara Self Efficacy dengan Penyesuaian akademik dan Prestasi Akademik. Jurnal Psikologi, Vol. 14, No. 22004.

Yuwanto, L., Siandhika, L., Budiman, A.F., \& Prasetyo, T.I Stres akademik dan flow akademik. Presented at Psychology Village 2 Harmotion: It"s
Universitas Pelita Harapan Jakarta, in Jakarta, 2011. 